Article

\title{
Assessment of Ecosystem Service Values of Urban Parks in Improving Air Quality: A Case Study of Wuhan, China
}

\author{
Qijiao Xie ${ }^{1,2}$, Yang Yue ${ }^{1}$, Qi Sun ${ }^{1}$, Si Chen ${ }^{1,2}$, Soo-Beom Lee ${ }^{3}$ and Seong Wook Kim ${ }^{4, *}$ \\ 1 School of Resources and Environmental Science, Hubei University, Wuhan 430062, China; \\ xieqijiao@126.com (Q.X.); yueyang428@163.com (Y.Y.); sq1631@126.com (Q.S.); \\ kathryncs123@hotmail.com (S.C.) \\ 2 Key Laboratory of Regional Development and Environmental Response, Wuhan 430062, China \\ 3 Department of Transportation Engineering, University of Seoul, Seoul 04763, Korea; mendota@uos.ac.kr \\ 4 Department of Applied Mathematics, Hanyang University, Ansan 15588, Korea \\ * Correspondence: seong@hanyang.ac.kr
}

Received: 30 September 2019; Accepted: 8 November 2019; Published: 19 November 2019

check for updates

\begin{abstract}
Assessing ecosystem service values of urban parks can promote understanding of urban green space protection and management. In this study, ecosystem services of air quality purification from 40 sample parks with different areas and land cover compositions were assessed based on literature records and high-resolution images. Six typical ecological benefits of $\mathrm{CO}_{2}$ sequestration, $\mathrm{O}_{2}$ generation, air temperature amelioration, $\mathrm{SO}_{2}$ removal, $\mathrm{NO}_{\mathrm{x}}$ removal, and dust interception were estimated. The results showed similar proportions of different ecosystem service values to total. The ecological services of $\mathrm{CO}_{2}$ sequestration and $\mathrm{O}_{2}$ generation contributed the majority of total ecosystem service value, with percentages ranging from $69.34 \%$ to $73.76 \%$ and from $20.52 \%$ to $21.71 \%$, respectively. There was very wide variation of ecosystem service values among urban parks. Multivariate regression between ecosystem service values and spatial characteristics of urban parks revealed that park areas of forest and water played a vital role in service value. For a given park, the total service value could be increased by up to $600 \%$ if the park was redesigned with consideration of land cover composition. This study provides sound scientific information for urban planners and greening designers to optimize urban park layout.
\end{abstract}

Keywords: ecosystem service; valuation; air quality; urban park

\section{Introduction}

As the only natural area in urbanized area, urban green spaces play an irreplaceable role in improving human habitat quality and maintaining healthy urban ecosystems [1,2]. In recent years, rapid urbanization has resulted in tremendous population growth and continuous expansion of built-up areas in cities. Consequently, increasing demands for buildings, roads, vehicles, and energy production increased pollutant emissions to the atmosphere [3-6]. Meanwhile, urban green spaces are gradually fragmented and often contain impervious surface areas, which seriously weaken the ecological service function of the urban green space system and reduce its ecosystem service values [7,8]. People usually pay attention to the aesthetic, social, and recreational contributions of urban parks [9,10], ignoring their ecological benefits. This misunderstanding of park services can lead to deviation in park design. Maximization of the ecological benefits of a park while retaining its recreational function is a challenge for park designers and managers [11,12]. Assessment of ecosystem service values of urban parks can promote understanding of urban green space protection and provide sound scientific evidence for urban park layout and management. 
Most studies have been conducted at a local scale through field measurements to obtain pollutant data and model the relationship between urban vegetation and air pollution [11,13-15]. Air purification efficiency of urban green spaces depends on park components of trees, shrubs, and/or herbaceous vegetation $[12,16,17]$. However, previous studies focused on one or a few urban parks, and the limited samples cannot provide enough evidence to determine the specific influence of urban green spaces on the environment. More information is needed on the impacts of vegetation composition and structure on air purification and climate regulation services of urban green spaces [18-20]. Geographic information technology allows collection of adequate urban vegetation characteristics based on highspatial resolution images in bounded time.

This study combined field investigation with high-resolution image analysis to obtain the spatial characteristics of 40 sample parks. Based on literature records, the ecosystem service values of $\mathrm{CO}_{2}$ sequestration, $\mathrm{O}_{2}$ generation, air temperature amelioration, $\mathrm{SO}_{2}$ removal, $\mathrm{NO}_{\mathrm{x}}$ removal, and dust interception were assessed. The relationships between park characteristics and ecosystem service values were modeled to detect the mechanisms of influence of urban parks based on their ecological functions.

\section{Materials and Methods}

\subsection{Study Area}

This study was conducted in Wuhan $\left(113^{\circ} 41^{\prime} \sim 115^{\circ} 05^{\prime} \mathrm{E}, 29^{\circ} 58^{\prime} \sim 31^{\circ} 22^{\prime} \mathrm{N}\right)$, the capital of Hubei province in China, and the largest city of Central China and the Yangtze River Economic Belt. In recent years, Wuhan has been experiencing rapid development and spatial expansion, which led to a series of environmental problems. To explore how urban parks produce ecological benefits, 40 sample urban parks with varied locations, sizes, and land cover compositions were considered, as shown in Figure 1. Detailed information of each park is listed in Table 1.

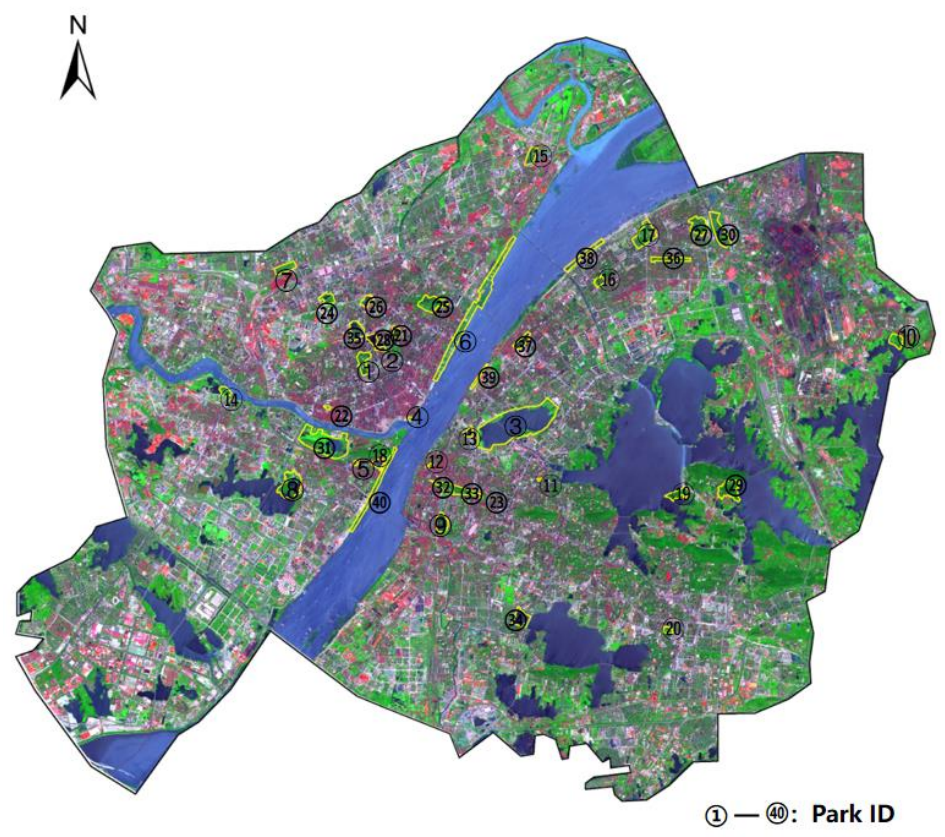

Figure 1. Locations of selected urban parks. 
Table 1. Detailed information of the selected urban parks.

\begin{tabular}{|c|c|c|c|c|c|c|c|c|c|c|}
\hline \multirow{2}{*}{ Park ID } & \multirow{2}{*}{ Park Name } & \multirow{2}{*}{$\begin{array}{c}\text { Total Area } \\
\left(\mathrm{hm}^{2}\right)\end{array}$} & \multicolumn{2}{|c|}{ Forest } & \multicolumn{2}{|c|}{ Lawn } & \multicolumn{2}{|c|}{ Water } & \multicolumn{2}{|c|}{ Built-up } \\
\hline & & & Area $\left(\mathrm{hm}^{2}\right)$ & Percentage & Area $\left(\mathrm{hm}^{2}\right)$ & Percentage & Area $\left(\mathrm{hm}^{2}\right)$ & Percentage & Area $\left(\mathrm{hm}^{2}\right)$ & Percentage \\
\hline 1 & Zhongshan & 30.49 & 19.15 & $62.83 \%$ & 2.56 & $8.40 \%$ & 3.40 & $11.16 \%$ & 5.37 & $17.61 \%$ \\
\hline 2 & Xiaonanhu & 6.05 & 1.81 & $29.93 \%$ & 0.57 & $9.39 \%$ & 2.57 & $42.40 \%$ & 1.11 & $18.27 \%$ \\
\hline 3 & Sha Lake & 324.62 & 28.21 & $8.69 \%$ & 19.73 & $6.08 \%$ & 259.26 & $79.87 \%$ & 17.42 & $5.37 \%$ \\
\hline 4 & Longwangmiao & 1.92 & 0.83 & $43.31 \%$ & 0.32 & $16.74 \%$ & 0.00 & $0.00 \%$ & 0.77 & $39.96 \%$ \\
\hline 5 & Hanyang & 2.23 & 1.53 & $68.62 \%$ & 0.24 & $10.80 \%$ & 0.10 & $4.58 \%$ & 0.36 & $16.00 \%$ \\
\hline 6 & Hankou Beach & 147.13 & 67.70 & $46.01 \%$ & 10.94 & $7.43 \%$ & 21.01 & $14.28 \%$ & 47.48 & $32.27 \%$ \\
\hline 7 & Changqing & 23.86 & 10.59 & $44.37 \%$ & 5.06 & $21.22 \%$ & 1.82 & $7.64 \%$ & 6.39 & $26.77 \%$ \\
\hline 8 & Wuhan Zoo & 67.31 & 25.02 & $37.18 \%$ & 4.40 & $6.53 \%$ & 28.63 & $42.54 \%$ & 9.25 & $13.75 \%$ \\
\hline 9 & Ziyang & 27.97 & 10.18 & $36.39 \%$ & 2.02 & $7.22 \%$ & 12.00 & $42.92 \%$ & 3.77 & $13.47 \%$ \\
\hline 10 & Baiyu & 21.80 & 9.25 & $42.43 \%$ & 8.43 & $38.65 \%$ & 1.03 & $4.72 \%$ & 3.10 & $14.20 \%$ \\
\hline 11 & Shuiguo Lake & 1.38 & 0.71 & $51.60 \%$ & 0.00 & $0.00 \%$ & 0.00 & $0.00 \%$ & 0.67 & $48.40 \%$ \\
\hline 12 & Wuchang & 2.13 & 1.24 & $58.38 \%$ & 0.38 & $17.88 \%$ & 0.00 & $0.00 \%$ & 0.50 & $23.74 \%$ \\
\hline 13 & Neisha Lake & 8.88 & 1.54 & $17.35 \%$ & 0.45 & $5.07 \%$ & 5.52 & $62.16 \%$ & 1.37 & $15.43 \%$ \\
\hline 14 & Hanshui & 11.30 & 4.98 & $44.04 \%$ & 2.13 & $18.82 \%$ & 2.67 & $23.66 \%$ & 1.52 & $13.47 \%$ \\
\hline 15 & Dijiao & 20.92 & 9.56 & $45.71 \%$ & 5.86 & $28.01 \%$ & 2.06 & $9.85 \%$ & 3.44 & $16.43 \%$ \\
\hline 16 & Kepu & 11.63 & 5.70 & $49.00 \%$ & 3.44 & $29.61 \%$ & 0.00 & $0.00 \%$ & 2.49 & $21.39 \%$ \\
\hline 17 & Peace & 55.47 & 27.15 & $48.94 \%$ & 13.07 & $23.56 \%$ & 2.37 & $4.27 \%$ & 12.89 & $23.24 \%$ \\
\hline 18 & Lotus Lake & 13.06 & 2.27 & $17.37 \%$ & 0.75 & $5.71 \%$ & 6.66 & $50.97 \%$ & 3.39 & $25.96 \%$ \\
\hline 19 & East Lake & 24.71 & 13.11 & $53.05 \%$ & 5.80 & $23.49 \%$ & 2.09 & $8.48 \%$ & 3.70 & $14.98 \%$ \\
\hline 20 & Dutch & 8.37 & 4.06 & $48.55 \%$ & 1.47 & $17.62 \%$ & 0.20 & $2.35 \%$ & 2.63 & $31.48 \%$ \\
\hline 21 & Baodao & 11.29 & 1.90 & $16.87 \%$ & 0.00 & $0.00 \%$ & 8.30 & $73.52 \%$ & 1.08 & $9.60 \%$ \\
\hline 22 & Qiekou & 2.89 & 1.67 & $57.71 \%$ & 0.19 & $6.63 \%$ & 0.13 & $4.37 \%$ & 0.91 & $31.29 \%$ \\
\hline 23 & Changchun Temple & 2.56 & 0.79 & $30.74 \%$ & 0.00 & $0.00 \%$ & 0.00 & $0.00 \%$ & 1.77 & $69.26 \%$ \\
\hline 24 & Houxianghe & 17.74 & 10.22 & $57.63 \%$ & 1.69 & $9.51 \%$ & 3.70 & $20.87 \%$ & 2.13 & $12.00 \%$ \\
\hline 25 & Jiefang & 46.78 & 29.69 & $63.47 \%$ & 7.22 & $15.44 \%$ & 4.47 & $9.55 \%$ & 5.40 & $11.54 \%$ \\
\hline 26 & Lingjiao Lake & 13.45 & 2.75 & $20.43 \%$ & 0.91 & $6.78 \%$ & 8.13 & $60.47 \%$ & 1.66 & $12.33 \%$ \\
\hline 27 & Qingshan & 37.22 & 20.96 & $56.30 \%$ & 5.87 & $15.78 \%$ & 3.94 & $10.59 \%$ & 6.45 & $17.32 \%$ \\
\hline 28 & Spring & 13.17 & 0.95 & $7.21 \%$ & 0.00 & $0.00 \%$ & 10.92 & $82.92 \%$ & 1.30 & $9.87 \%$ \\
\hline 29 & Plant & 47.07 & 27.60 & $58.63 \%$ & 10.89 & $23.15 \%$ & 2.82 & $6.00 \%$ & 5.75 & $12.22 \%$ \\
\hline 30 & Daijia Lake & 51.91 & 17.82 & $34.34 \%$ & 19.73 & $38.01 \%$ & 5.02 & $9.67 \%$ & 9.33 & $17.98 \%$ \\
\hline 31 & Moon Lake & 143.47 & 38.55 & $26.87 \%$ & 18.94 & $13.20 \%$ & 60.03 & $41.84 \%$ & 25.95 & $18.08 \%$ \\
\hline 32 & Yellow Crane Tower & 22.51 & 11.39 & $50.58 \%$ & 0.00 & $0.00 \%$ & 0.00 & $0.00 \%$ & 11.12 & $49.42 \%$ \\
\hline 33 & Shouyi & 20.83 & 15.10 & $72.49 \%$ & 0.00 & $0.00 \%$ & 0.00 & $0.00 \%$ & 5.73 & $27.51 \%$ \\
\hline 34 & Xinfuwan & 31.23 & 3.30 & $10.57 \%$ & 4.35 & $13.93 \%$ & 20.72 & $66.36 \%$ & 2.86 & $9.15 \%$ \\
\hline 35 & Northwest Lake & 31.36 & 6.82 & $21.75 \%$ & 0.00 & $0.00 \%$ & 11.80 & $37.62 \%$ & 12.74 & $40.63 \%$ \\
\hline 36 & South Main Channel & 22.70 & 11.21 & $49.38 \%$ & 3.33 & $14.68 \%$ & 0.00 & $0.00 \%$ & 8.16 & $35.94 \%$ \\
\hline 37 & Simeitang & 19.93 & 5.79 & $29.06 \%$ & 2.01 & $10.07 \%$ & 6.81 & $34.18 \%$ & 5.32 & $26.70 \%$ \\
\hline 38 & Linjiang & 27.93 & 8.35 & $29.91 \%$ & 5.55 & $19.86 \%$ & 0.00 & $0.00 \%$ & 14.03 & $50.22 \%$ \\
\hline 39 & Hanyang Beach & 46.88 & 2.53 & $5.40 \%$ & 21.57 & $46.02 \%$ & 0.00 & $0.00 \%$ & 22.78 & $48.58 \%$ \\
\hline 40 & Wuchang Beach & 8.79 & 1.65 & $18.73 \%$ & 3.60 & $40.93 \%$ & 0.00 & $0.00 \%$ & 3.55 & $40.34 \%$ \\
\hline
\end{tabular}




\subsection{Land Cover Classification}

For each park, the boundary was delineated based on a Google Earth image and field investigation. The land cover in each park was divided into four categories: (1) Forest:greater than $90 \%$ canopy cover by arbors and shrubs; (2) Lawn: vegetated area covered by grass with less than $90 \%$ coverage of arbor sand shrubs; (3) Water: all water bodies in a park, including natural lakes, rivers, ponds, and artificial fountains; (4) Built-up: impervious surfaces including buildings, squares, roads, and parking lots. For each land cover type, about 30 samples wererandomly selected to verify the classification accuracy. The overall classification accuracy is over $95 \%$, which meets the research requirements.

\subsection{Ecological Service Value Calculation}

In most cities, the major air pollutants can be identified as particulates, carbon, nitrogen oxides, sulfur oxides, hydrocarbons, photochemical smog, and inorganic compounds [21]. In this study, $\mathrm{CO}_{2}$ sequestration, $\mathrm{O}_{2}$ generation, air temperature amelioration, $\mathrm{SO}_{2}$ removal, $\mathrm{NO}_{\mathrm{x}}$ removal, and dust interception were selected as the indexes of ecological benefits in air quality. As a kind of nature-based solution, urban vegetation was efficient in improving air quality through green leaves and dense canopies. However, urban parks differ in vegetation coverage, canopy density, leaf amount, and area. Thus, it is necessary to calculate the ecological benefits of different park components. For each park, the overall ecological service value can be calculated as

$$
E=\sum_{i=1}^{3} \sum_{j=1}^{7} A_{i} \times Q_{i j} \times K_{j}
$$

where $E$ is the ecosystem service value in improving air quality, $i$ denotes the land cover type (referring to Forest, Lawn, and Water), $j$ denotes the ecological service type (referring to $\mathrm{CO}_{2}$ sequestration, $\mathrm{O}_{2}$ generation, air temperature amelioration, $\mathrm{SO}_{2}$ removal, $\mathrm{NO}_{\mathrm{x}}$ removal, and dust interception), $A_{i}$ is the area of land cover type $i, Q_{i j}$ is the per unit benefit of land cover type $i$ for ecological service type $j$, and $K_{j}$ is the per unit economic value of ecological service type $j$. The related information for economic valuation of ecological services for urban parks in the Wuhan urbanized area is summarized in Table 2.

Table 2. Economic valuation of ecological services for urban parks in the Wuhan urbanized area.

\begin{tabular}{|c|c|c|c|}
\hline Ecosystem Service & Estimated Content & Calculation Method & Unit Value \\
\hline $\mathrm{CO}_{2}$ Sequestration & $\begin{array}{l}\mathrm{CO}_{2} \text { stored through } \\
\text { photosynthesis }\end{array}$ & Carbon tax & $1012 \mathrm{RMB} /$ tonne \\
\hline $\mathrm{O}_{2}$ Generation & $\begin{array}{l}\mathrm{O}_{2} \text { produced through } \\
\text { photosynthesis }\end{array}$ & Market value & $400 \mathrm{RMB} /$ tonne \\
\hline $\begin{array}{l}\text { Air Temperature } \\
\text { Amelioration }\end{array}$ & $\begin{array}{l}\text { Plant transpiration and } \\
\text { water evaporation }\end{array}$ & Market value & $0.573 \mathrm{RMB} / \mathrm{kw} \cdot \mathrm{h}$ \\
\hline $\mathrm{SO}_{2}$ Removal & $\mathrm{SO}_{2}$ absorbed by plants & Shadow project price & $3 \mathrm{RMB} / \mathrm{kg}$ \\
\hline $\mathrm{NO}_{\mathrm{x}}$ Removal & $\mathrm{NO}_{\mathrm{x}}$ absorbed by plants & Shadow project price & $1.6 \times 10^{4} \mathrm{RMB} /$ tonne \\
\hline Dust Interception & $\begin{array}{l}\text { Dust absorbed and } \\
\text { adsorbed by vegetation }\end{array}$ & Shadow project price & $170 \mathrm{RMB} /$ tonne \\
\hline
\end{tabular}

Note: RMB indicates Chinese Yuan; tonne indicates metric tons $(1000 \mathrm{~kg})$.

\subsection{1. $\mathrm{CO}_{2}$ Sequestration}

The carbon sequestration amount of each park was calculated based on the sum of trees, shrubs, and grass using literature values. According to studies conducted in Wuhan, mean carbon sequestration per unit of forest land and grassland are 149.23 tonne $/ \mathrm{hm}^{2}$ and 63.55 tonne $/ \mathrm{hm}^{2}$, respectively [22]. Mean carbon sequestration per unit of water is 0.22 tonne $/ \mathrm{hm}^{2}$, which was calculated based on photosynthesis of aquatic plants [23]. A carbon tax of US\$150/tonne (about 1012Chinese Yuan (RMB)/tonne) of carbon emission from the Swedish government was adopted for valuing the ecological service of $\mathrm{CO}_{2}$ sequestration. 


\subsection{2. $\mathrm{O}_{2}$ Generation}

Urban vegetation can generate $\mathrm{O}_{2}$ through photosynthesis. The $\mathrm{O}_{2}$ amount produced from urban parks depends on mean net leaf photosynthetic rate of plants in a park, which varies depending on forest, lawn, and water areas. Previous studies show that the mean $\mathrm{O}_{2}$ generation per unit forest, lawn, and water areas is 109.53 tonne $/ \mathrm{hm}^{2}, 46.18$ tonne $/ \mathrm{hm}^{2}$, and 0.17 tonne $/ \mathrm{hm}^{2}$, respectively [22,23]. The cost of producing $\mathrm{O}_{2}$ through industrial processes was used in this study to estimate the benefit of $\mathrm{O}_{2}$ generation [22] at a value of $400 \mathrm{RMB} /$ tonne.

\subsubsection{Air Temperature Amelioration}

Urban parks provide the ecological service of air temperature amelioration through water vapor evaporation and plant transpiration. Average annual evaporation per unit water area in Wuhan is $927.1 \mathrm{~mm}$. Based on the water area in parks, the overall evaporation of water bodies can be obtained. The ecological service value of evaporative cooling was calculated as $0.129 \mathrm{RMB}$ per unit [24]. For forest and grass areas, the transpiration amount is $22.61 \times 10^{6} \mathrm{KJ} / \mathrm{hm}^{2}$ and $11.75 \times 10^{6} \mathrm{KJ} / \mathrm{hm}^{2}$ per unit area [22], respectively. With the residential electricity price at $0.573 \mathrm{RMB} / \mathrm{kw} \cdot \mathrm{h}[25]$, transpiration cooling can be valued.

\subsection{4. $\mathrm{SO}_{2}$ Removal}

The $\mathrm{SO}_{2}$ removal per unit forest area was based on the average amounts per broad-leaved and coniferous tree [26,27], with a value of $152.13 \mathrm{~kg} / \mathrm{hm}^{2}$. For the land cover type of lawn, the value is $279.03 \mathrm{~kg} / \mathrm{hm}^{2}$ [27]. As aquatic plants absorb only a small amount of sulfur oxides from the atmosphere, the ecological service of $\mathrm{SO}_{2}$ removal by water was neglected in this study. According to the literature [28], the marginal cost of $\mathrm{SO}_{2}$ in China is $3 \mathrm{RMB} / \mathrm{kg}$, which can be used to determine the monetary value of the $\mathrm{SO}_{2}$ removal of each park.

\subsection{5. $\mathrm{NO}_{\mathrm{x}}$ Removal}

Previous studies have indicated that $\mathrm{NO}_{x}$ removal per unit forest and unit grass land is $380 \mathrm{~kg} / \mathrm{hm}^{2}$ and $6 \mathrm{~kg} / \mathrm{hm}^{2}$, respectively $[28,29]$. The benefit of $\mathrm{NO}_{\mathbf{x}}$ removal in water bodies can be neglected. The vehicle exhaust denitrification treatment cost was used in calculating the ecological service value of $\mathrm{NO}_{\mathrm{x}}$ removal, with a value of $16,000 \mathrm{RMB} /$ tonne [30].

\subsubsection{Dust Interception}

The efficiency of urban plants in intercepting dust and particles is influenced by leaf characteristics, canopy structure, green space composition, rainfall, and precipitation density. Based on the literature, dust retention per unit area of trees and shrubs wasaveraged to estimate the unit dust interception forforest land cover. The dust amounts intercepted per forest, grass, and water area are 24.57 tonne $/ \mathrm{hm}^{2}$, 2.6 tonne $/ \mathrm{hm}^{2}$ [22], and 49.8 tonne $/ \mathrm{km}^{2}$ [31], respectively. In China, the industrial dust control cost is about $170 \mathrm{RMB} /$ tonne, which was adopted as the reference for calculating ecological service values in the present study.

\section{Results}

\subsection{Park Composition}

As introduced in the previous chapter, we considered four typical land cover compositions for each urban park: forest, lawn, water, and built-up. Table 1 shows the corresponding areas, with Sha Lake Park (Park ID: 3) having the largest total area of $324.62 \mathrm{hm}^{2}$ and Shuiguo Lake Park (ParkID: 11) having the smallest total area of only $1.38 \mathrm{hm}^{2}$. In terms of percentage of each land cover type, we focused on forest, lawn, and water since built-up was not taken into consideration in the subsequent ecological service value calculation. Table 1 shows that Spring Park (ParkID: 28) exhibited the maximum 
composition percentage for water at $82.92 \%$, and the maximum composition percentage for forest was in Shouyi Park (ParkID: 33) with $72.49 \%$, while the maximum value for lawn was $46.02 \%$ in Hanyang Beach Park (ParkID: 39). The various composition percentages of land types in the parks contributed to different ecological service functions and resulted in significant disparity in total ecological values.

\subsection{Ecological Service Values}

To compare the service values of the previously mentioned ecological functions among urban parks, we calculated the ecological service values for $\mathrm{CO}_{2}$ sequestration, $\mathrm{O}_{2}$ generation, air temperature amelioration, $\mathrm{SO}_{2}$ removal, $\mathrm{NO}_{\mathrm{x}}$ removal, dust interception, and the total value for each park. These values were plotted as colored bars at the location of each park in the map, as shown in Figure 2, with bar length indicating the corresponding value of each ecological function. The figure shows that the parks generally showed consistent performance for the various ecological functions proportional to park area, i.e., the parks with larger area contributed larger amounts to the total ecological values, as shown in Figure 2g, and the parks showing larger/smaller values for one ecological function generally showed larger/smaller values for the other functions, as shown in Figure 2a-f. However, Jiefang Park (ParkID: 25) with a limited area of $46.78 \mathrm{hm}^{2}$ was an exception, showing the largest ecological service values for $\mathrm{CO}_{2}$ sequestration, $\mathrm{O}_{2}$ generation, $\mathrm{SO}_{2}$ removal, $\mathrm{NO}_{\mathrm{x}}$ removal, dust interception, and total ecological value. These results were due to the rather large composition percentage $(63.47 \%)$ of forest land type in Jiefang Park. Comparatively, Sha Lake Park (ParkID: 3) with the largest area $\left(324.62 \mathrm{hm}^{2}\right)$ had a composition percentage of $8.69 \%$ for forest, with the largest composition percentage for water $(79.87 \%)$.

As shown in Figure 2, urban parks play an important role in each ecological function. However, various service values must be considered to investigate the proportion of each function to the total ecological value; Figure 3 plots the benefit percentages of the six ecological functions for each urban park. Overall, the parks showed consistent order of the proportions of ecological function, in descending order of $\mathrm{CO}_{2}$ sequestration, $\mathrm{O}_{2}$ generation, air temperature amelioration, $\mathrm{NO}_{\mathrm{x}}$ removal, dust interception, and $\mathrm{SO}_{2}$ removal. The greatest ecological service contribution to $\mathrm{CO}_{2}$ sequestration produced a benefit percentage of $69.34 \%$ to $73.76 \%$, while the smallest percentage forSO $_{2}$ removal ranged from $0.21 \%$ to $0.81 \%$.

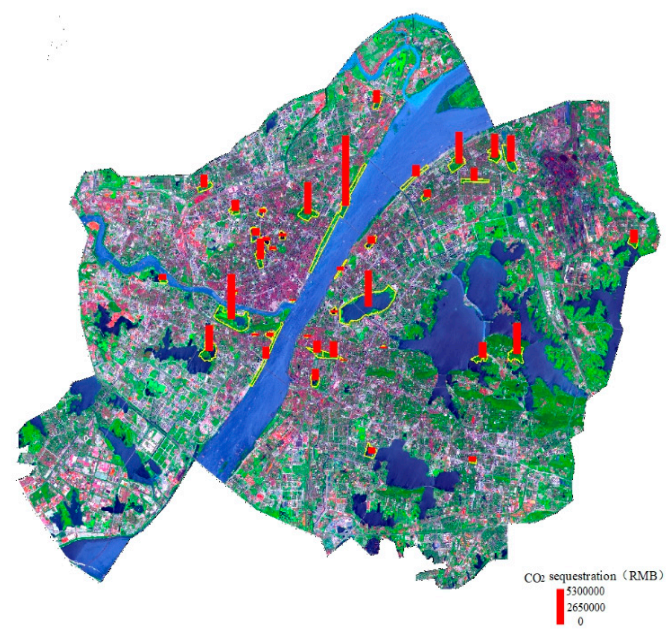

(a)

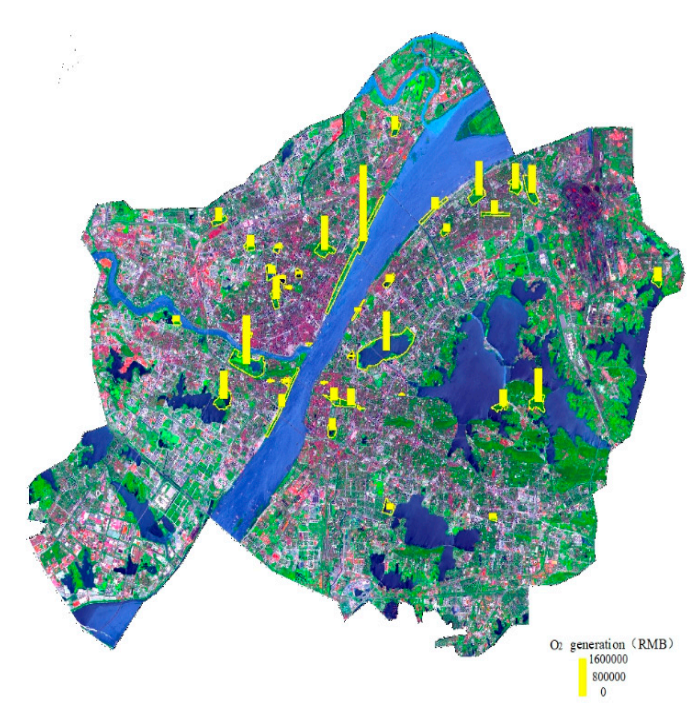

(b)

Figure 2. Cont. 


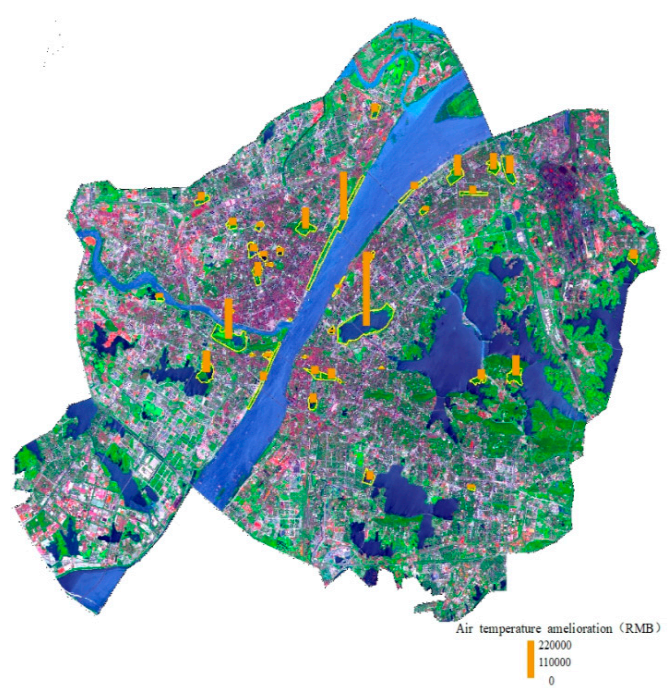

(c)

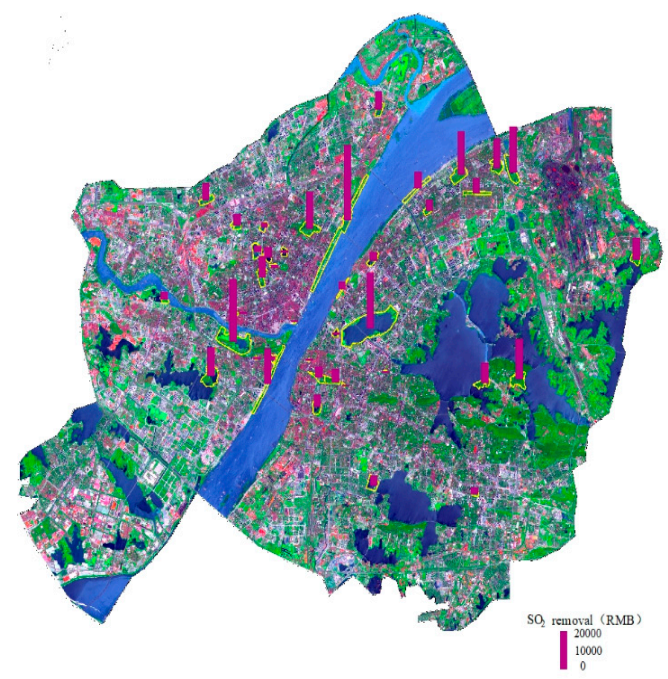

(e)

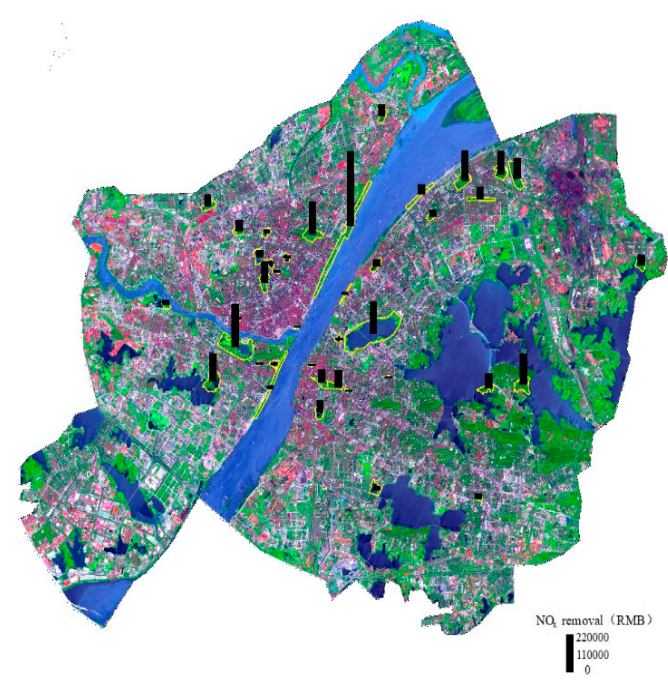

(d)

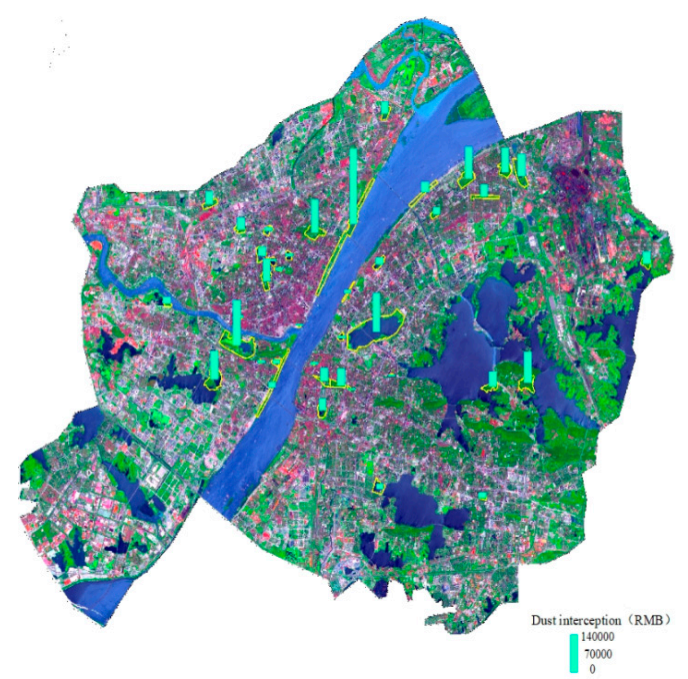

(f)

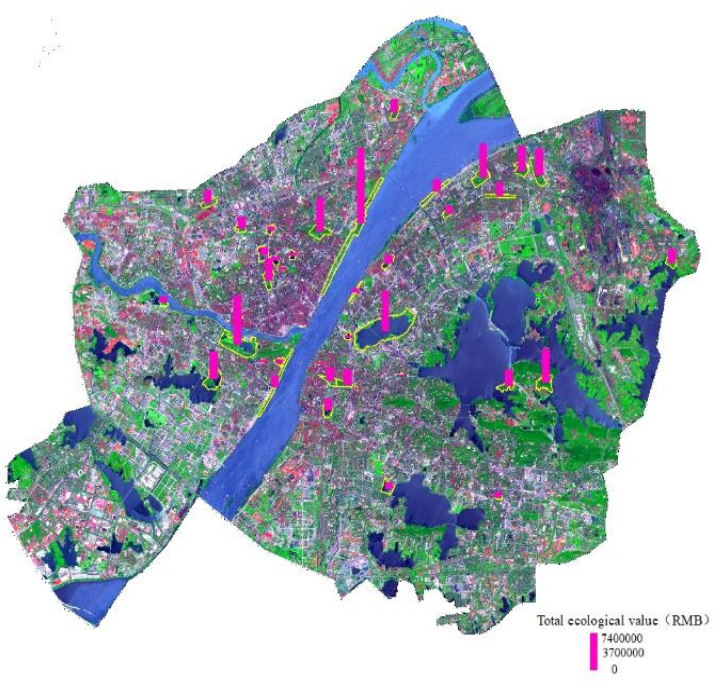

(g)

Figure 2. Ecological service values for individual ecological functions and total ecological value for each urban park: (a-g) represent $\mathrm{CO}_{2}$ sequestration, $\mathrm{O}_{2}$ generation, air temperature amelioration, $\mathrm{SO}_{2}$ removal, $\mathrm{NO}_{\mathrm{x}}$ removal, dust interception, and total ecological value, respectively. 


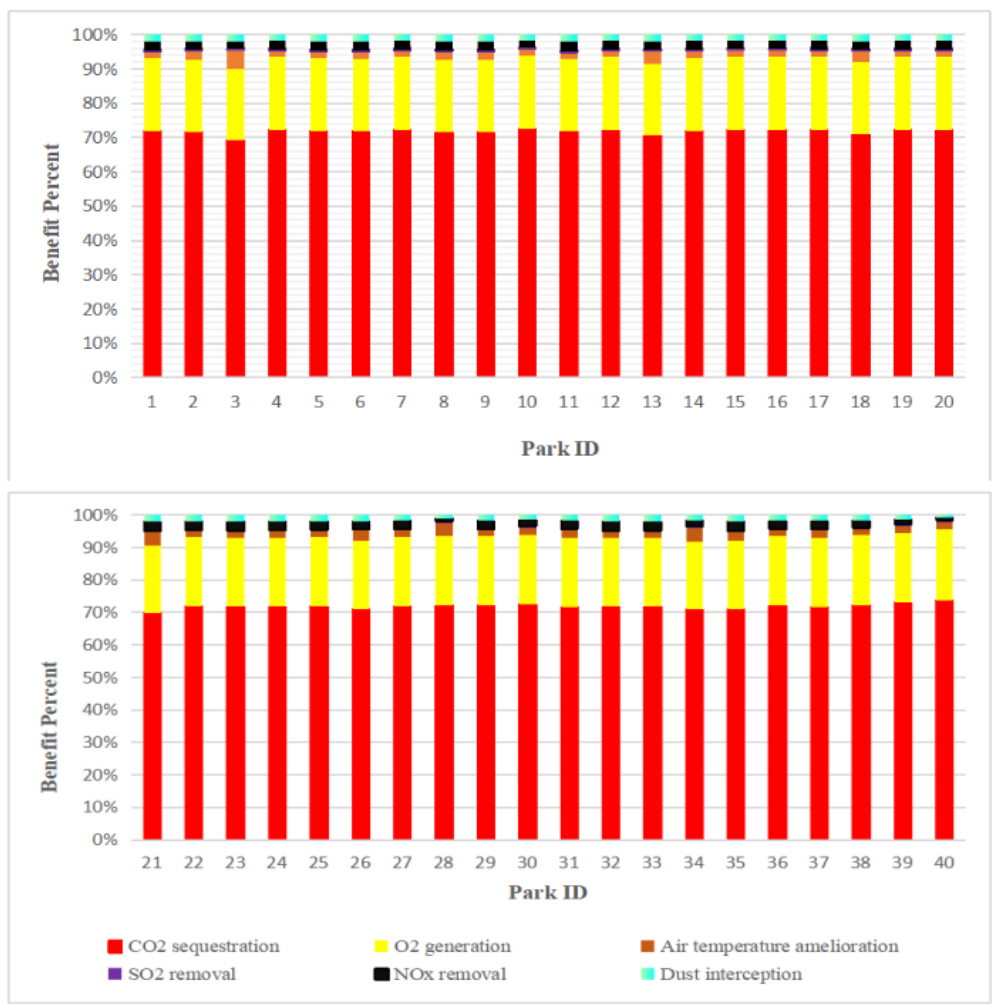

Figure 3. Percentages of ecological service values of each function in the total ecological value for selected urban parks.

\subsection{Response of Ecological Service Values to Park Composition}

Land cover type had various effects on the service values of different ecological functions. To determine the dominant land cover type for each function and the total ecological value, multivariate regression analysis was performed between the dependent variables (i.e., six ecological functions and total values) and independent variables (i.e., forest, lawn, and water areas). The regression equations and corresponding $\mathrm{R}^{2}$ values are listed in Table 3. For all ecological functions except air temperature amelioration, area of forest played a vital role in service value; the larger the area of forest, the greater the value of $\mathrm{CO}_{2}$ sequestration, $\mathrm{O}_{2}$ generation, $\mathrm{NO}_{\mathrm{x}}$ removal, dust interception, and $\mathrm{SO}_{2}$ removal. However, for air temperature amelioration, water bodies in a park produced a larger cooling effect than the forest, and the lawn showed little impact. Thus, water and forest were significant drivers of air temperature amelioration. $\mathrm{NO}_{\mathrm{x}}$ removal was only affected by forest. When considering total ecological value, the largest effect was produced by forest.

Table 3. Regression analysis results for ecological service functions and land cover area.

\begin{tabular}{cccc}
\hline Dependent Variable & Independent Variable & Regression Equation & $\mathbf{R}^{\mathbf{2}}$ \\
\hline $\mathrm{CO}_{2}$ Sequestration $\left(\mathrm{V}_{1}\right)$ & Forest $\left(\mathrm{X}_{1}\right)$, Lawn $\left(\mathrm{X}_{2}\right)$ & $\mathrm{V}_{1}=38.646 \mathrm{X}_{1}+4.580 \mathrm{X}_{2}+1.043$ & 0.985 \\
$\mathrm{O}_{2}$ Generation $\left(\mathrm{V}_{2}\right)$ & Forest $\left(\mathrm{X}_{1}\right)$, Lawn $\left(\mathrm{X}_{2}\right)$ & $\mathrm{V}_{2}=38.980 \mathrm{X}_{1}+4.573 \mathrm{X}_{2}+1.043$ & 0.986 \\
Air Temperature & Forest $\left(\mathrm{X}_{1}\right)$, Lawn $\left(\mathrm{X}_{2}\right)$, Water $\left(\mathrm{X}_{3}\right)$ & $\mathrm{V}_{3}=32.596 \mathrm{X}_{1}+3.951 \mathrm{X}_{2}+35.450 \mathrm{X}_{3}+1.167$ & 0.992 \\
Amelioration $\left(\mathrm{V}_{3}\right)$ & Forest $\left(\mathrm{X}_{1}\right)$, Lawn $\left(\mathrm{X}_{2}\right)$ & $\mathrm{V}_{4}=10.779 \mathrm{X}_{1}+5.516 \mathrm{X}_{2}+1.068$ & 0.890 \\
$\mathrm{SO}_{2}$ Removal $\left(\mathrm{V}_{4}\right)$ & Forest $\left(\mathrm{X}_{1}\right)$ & $\mathrm{V}_{5}=318.444 \mathrm{X}_{1}+0.769$ & 1.000 \\
$\mathrm{NO}_{\mathrm{x}}$ Removal $\left(\mathrm{V}_{5}\right)$ & Forest $\left(\mathrm{X}_{1}\right)$, Lawn $\left(\mathrm{X}_{2}\right)$ & $\mathrm{V}_{6}=116.513 \mathrm{X}_{1}+2.151 \mathrm{X}_{2}+8.901 \mathrm{X}_{3}+1.156$ & 0.998 \\
Dust Interception $\left(\mathrm{V}_{6}\right)$ & Forest $\left(\mathrm{X}_{1}\right)$, Lawn $\left(\mathrm{X}_{2}\right)$, Water $\left(\mathrm{X}_{3}\right)$ & $\mathrm{V}_{7}=37.046 \mathrm{X}_{1}+3.858 \mathrm{X}_{2}+35.652 \mathrm{X}_{3}+1.167$ & 0.993 \\
Total Value $\left(\mathrm{V}_{7}\right)$ & & & \\
\hline
\end{tabular}




\section{Discussion}

\subsection{Necessity}

Most previous studies confirmed that urban green spaces produce multiple ecological benefits in improving air quality $[1,2,8]$. Ecosystem service values can be estimated based on the area of green space and the ecological benefits per unit green area. The latter were usually obtained by field measurements on small scale $[8,12,15,22]$, providing accurate and instantaneous data. On a larger scale, they werereferenced from empirical values from the literature $[18,20,23,26]$, which variedwith the pollution concentration, amount of precipitation, and green biomass in green spaces. In a given city, the influence of pollution level and rainfall on the ecological capacity of urban green space in air purification is generally negligible $[1,8]$. However, green biomass of green space depends on vegetation coverage and leaf area index. Green spaces with different composition, structure, and plant species have a different capacity forremoving pollutants from the atmosphere $[15,16]$. It is necessary to consider the area proportion of different elements in green space, rather than only the area of green space when calculating the ecological service values.

Table 4 lists the maximum, minimum, and average ecological benefits per unit for $\mathrm{CO}_{2}$ sequestration, $\mathrm{O}_{2}$ generation, $\mathrm{SO}_{2}$ removal, $\mathrm{NO}_{\mathrm{x}}$ removal, and dust interception based on 40 tested parks. Wide variation of ecological benefit per unit among parks was found for all selected ecosystem service types with higher standard deviation values. The highest standard deviation value was presented for the per unit benefit of $\mathrm{SO}_{2}$ removal, with a value of $108.03 \mathrm{~kg} / \mathrm{hm}^{2}$ while the average value wasonly $115.31 \mathrm{~kg} / \mathrm{hm}^{2}$. The biggest difference among parks is the per unit benefit of $\mathrm{CO}_{2}$ sequestration, and the maximum value was nearly 20 times the minimum one. For each park, the per unit ecological benefit is the total ecological benefit divided by park area. If land cover composition in a park was not considered in estimating ecological services, the obtained unit ecological benefits in this study would be equal to the empirical values from the literature. However, the actual values from the present study not only differed from the reference values but also varied among the tested parks (shown in Table 4).

Table 4. Difference of ecological benefitper $\mathrm{hm}^{2}$.

\begin{tabular}{cccccccc}
\hline \multirow{2}{*}{ Ecological Service } & \multicolumn{3}{c}{ Our Values } & \multicolumn{3}{c}{ Literature Values [22,23,25-28,30,31] } \\
\cline { 2 - 8 } & Maximum & Minimum & Average & Std & Forest & Lawn & Water \\
\hline $\mathrm{CO}_{2}$ Sequestration $\left(\right.$ tonne $\left./ \mathrm{hm}^{2}\right)$ & 198.90 & 10.12 & 71.61 & 34.83 & 149.23 & 63.55 & 0.22 \\
$\mathrm{O}_{2}$ Generation $\left(\right.$ tonne $\left./ \mathrm{hm}^{2}\right)$ & 80.08 & 7.39 & 52.47 & 25.45 & 109.53 & 46.18 & 0.17 \\
$\mathrm{SO}_{2}$ Removal $\left(\mathrm{kg} / \mathrm{hm}^{2}\right)$ & 158.29 & 25.67 & 115.31 & 108.03 & 152.13 & 279.03 & - \\
$\mathrm{NO}_{\mathbf{x}}$ Removal $\left(\mathrm{kg} / \mathrm{hm}^{2}\right)$ & 247.13 & 13.81 & 151.44 & 68.57 & 380 & 6 & - \\
Dust Interception $\left(\right.$ tonne/hm $\left./ \mathrm{hm}^{2}\right)$ & 17.81 & 1.06 & 10.34 & 4.38 & 24.57 & 2.6 & 0.498 \\
\hline
\end{tabular}

\subsection{Application}

Considering the effects of various land cover types on the total ecological value, a larger proportion of forest showed the highest ecological value. Urban planning should maximize ecosystem service value while ensuring recreational functions of urban parks. Thus, this study attempted to explore the variation of total ecological values with changes in land cover composition of parks while neglecting the built-up type to ensure basic recreational function. To indicate the discrepancy of ecological values caused by different land cover proportions (except built-up), we selected two typical urban parks, Jiefang Park (Park ID: 25) and Xingfuwan Park (Park ID: 34), which had land cover areas of forest, lawn, and water at $29.69 \mathrm{hm}^{2}, 7.22 \mathrm{hm}^{2}$, and $4.47 \mathrm{hm}^{2}$ and at $3.30 \mathrm{hm}^{2}, 4.35 \mathrm{hm}^{2}, 20.72 \mathrm{hm}^{2}$, respectively. The corresponding composition percentages of forest, lawn, and water for these two parks were $81.70 \%, 12.85 \%$, and $5.45 \%$ and $11.63 \%, 15.33 \%$, and $73.04 \%$, respectively. These values were selected as the expected maximum/minimum cases to update the corresponding area of each land cover area and to generate total ecological values for all urban parks. Results are shown in Figure 4, 
with positive/negative variation percentage indicating the expected increase/decrease in total ecological value for each park.

Based on the expected maximum case, with a reasonably large proportion of forest, most of the parks could achieve a significant increase in total ecological value; in particular, Sha Lake Park (Park ID: 3) could obtain an increase as large as 600\%. However, based on the expected minimum case, all but two parks exhibited a serious decrease in total ecological value, varying from $4.13 \%$ to $91.49 \%$. The overall results indicate that a reasonable proportion of land cover type can lead to significant variation in total ecological value, with a larger percentage of forest contributing to greater ecological values.
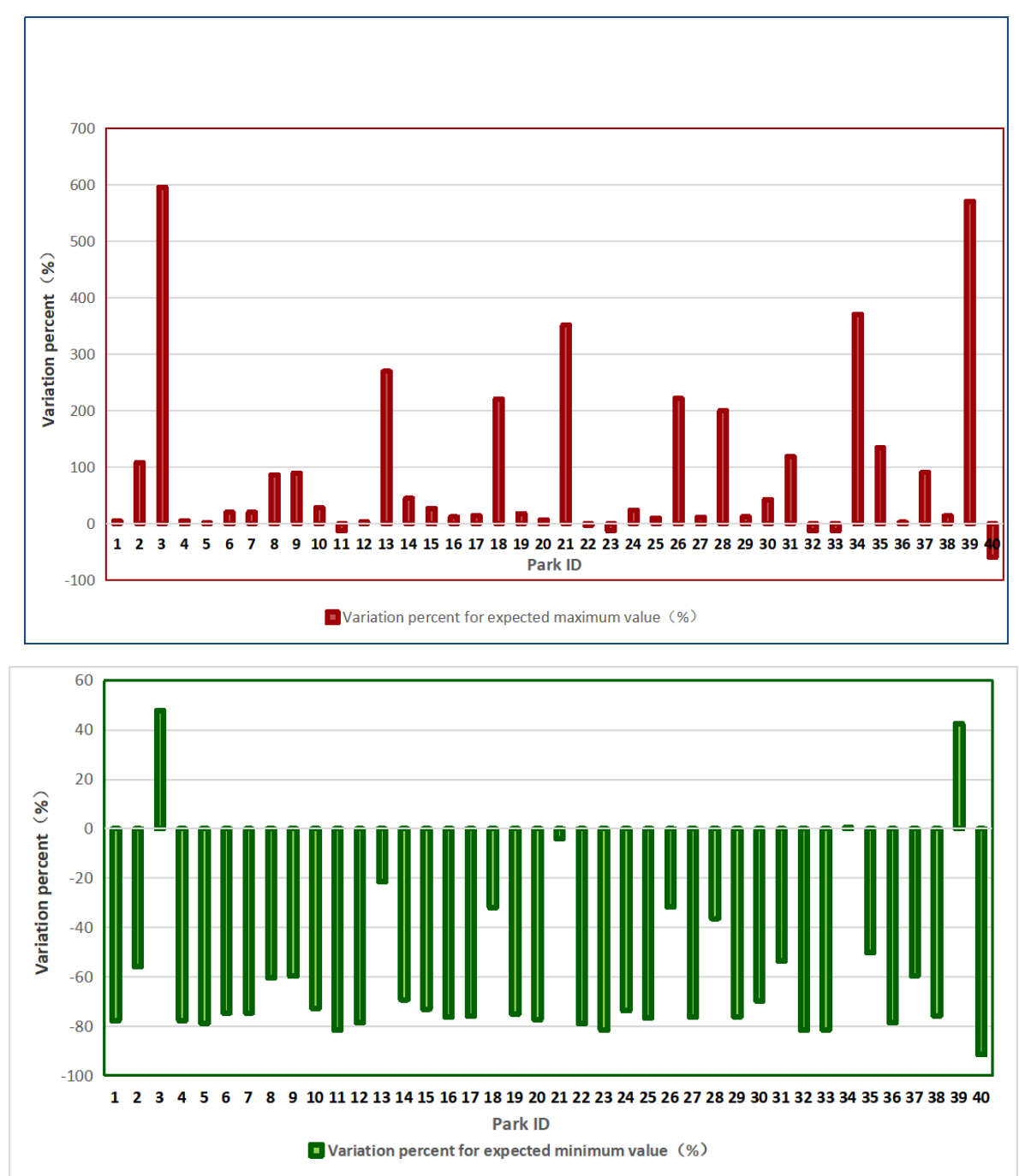

Figure 4. Percentages of the expected maximum and minimum ecological service values for selected urban parks.

\subsection{Limitation and Prospects}

Ecosystem service values of urban parks in improving air quality were assessed based on the literature results. The empirical values mainly came from our study area, which reduces the impact of regional climate, pollution level, and plant species on benefit production of green space. The studies we referred to were conducted on sunny days in different seasons, with varied urban contexts taken into consideration. When calculating ecological service value, the benefit differences of forest, grassland, and water bodies within the parks were considered, which effectively improved the estimation accuracy. However, the exact information on vegetation structure, species composition, 
and canopy density of the urban parks was not clear, which could partly influence the research results. Understanding the subtle structural differences in green spaces demands a spatially explicit design, with high spatial resolution [12]. As in some previous studies [8,23,26], this study did not consider the impact of environmental pollution condition on park air purification capacity. In other words, our investigation assumed that there were no differences among the estimated parks in terms of air pollution concentration and deposition velocity. This may have a slight impact on the estimates. In addition, estimation of ecosystem services mainly involved the removal of pollutants from the atmosphere, excluding those from the soil. Material and energy exchange between the surface and the near surface is significantly affected by land surface characteristics [32,33], which have a high degree of spatial heterogeneity in urban areas. Exchange mechanism of soil and air pollutants at a local scale should be considered in related research and scaled up to that of city scale. Urban parks provide a lot of benefits of air purification for urban residents, especially for those living near the parks. Most of them are high-income people, who can share larger park areas and enjoy more health promotion and well-being than low-income ones $[34,35]$. Future work could pay more attention to the social equity of urban parks.

\section{Conclusions}

Combined with previous research results, high-resolution images were used to assess the ecosystem services of urban parks with different areas and land cover compositions. Six typical ecological service functions of $\mathrm{CO}_{2}$ sequestration, $\mathrm{O}_{2}$ generation, air temperature amelioration, $\mathrm{SO}_{2}$ removal, $\mathrm{NO}_{x}$ removal, and dust interception were estimated. There was very wide variation of ecosystem service value among urban parks, with the maximum value of more than 14 million RMB being almost 1000 times larger than the minimum. However, all urban parks showed similar proportions of the different ecological benefits. The ecological services of $\mathrm{CO}_{2}$ sequestration and $\mathrm{O}_{2}$ generation contributed most to the total ecosystem service value, with percentages ranging from $69.35 \%$ to $73.77 \%$ and from $20.52 \%$ to $21.71 \%$, respectively (see Table A1 in Appendix A). Urban parks were confirmed to be important natural carbon sinks and oxygen sources. Although the other four ecological services had relatively lower values and proportions, they are also of great significance for improving urban air quality.

Land cover composition for a given park significantly influences the ecosystem service values. The ecological service of air temperature amelioration from forest coverage was almost equal to that of water bodies, and forest area played a dominant role in ecological service assessment. If all sample parks in this study were redesigned with areasonable land cover composition, the total services values would be greatly increased, with the largest increase up to $600 \%$. Through proper planning, design, and management of urban green spaces, ecological benefit can be maximized. The findings herein provide sound scientific information for urban planners and green designers to optimize urban park layout.

Author Contributions: Conceptualization, Q.X.; methodology, Y.Y.; software, Q.X. and Y.Y.; validation, S.W.K.; formal analysis, S.W.K.; investigation, Y.Y. and Q.S.; resources, Q.S.; data curation, Y.Y.; writing—original draft preparation, Q.X. and S.C.; writing-review and editing, S.-B.L. and S.W.K.; visualization, S.C.; supervision, S.C.; project administration, Q.X.; funding acquisition, Q.X. and S.C.

Funding: This research was sponsored by the National Natural Science Foundation of China (41401186), the Natural Science Foundation of Hubei Province of China (2019CFB538), and the Natural Science Foundation of Hubei Province of China (2019CFB188). Kim was partially supported by the Basic Science Research Program through the National Research Foundation of Korea (NRF) funded by the Ministry of Education (NRF-2018R1D1A1B07045804). Lee was supported by a 2017 sabbatical year research grant of University of Seoul.

Conflicts of Interest: The authors declare no conflict of interest. 


\section{Appendix A}

Table A1. Ecological service values and the corresponding percentages of urban parks.

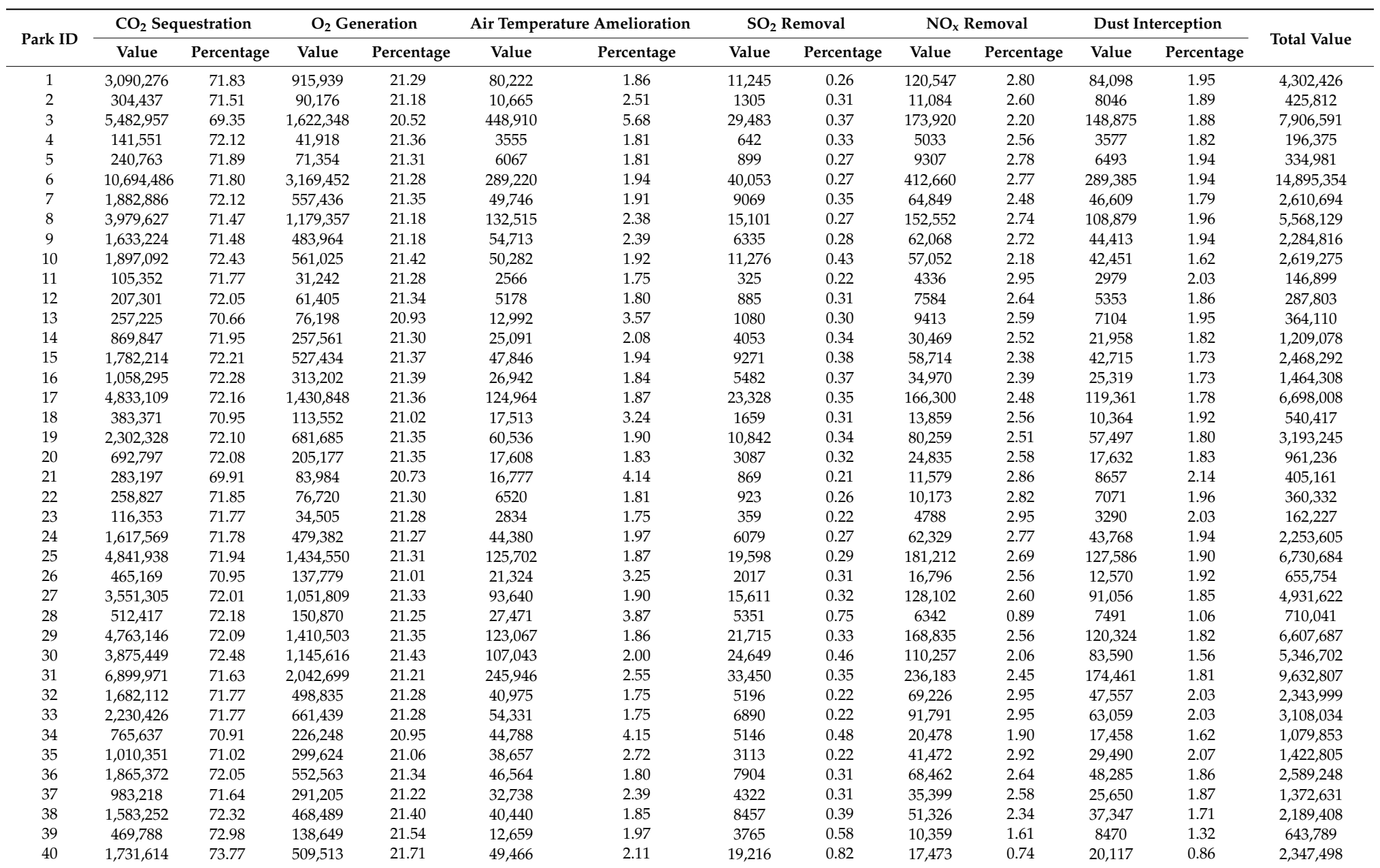

Note: Value indicates the ecological service value foreach function, unit: RMB; total value indicates the total ecological service value by summing all functions, unit: RMB; percentage indicates the ratio of ecological service value foreach function and the total ecological service value, unit: \%. 


\section{References}

1. Tzoulas, K.; Korpela, K.; Venn, S.; Yli-Pelkonen, V.; Kaz'miercak, A.; Niemela, J.; James, P. Promoting ecosystem and human health in urban areas using greens pace infrastructure: A literature review. Landsc. Urban Plan. 2007, 81, 167-178. [CrossRef]

2. Zupancic, T.; Westmacott, C.; Bulthuis, M. The Impact of Green Space on Heat and Air Pollution in Urban Communities: A Meta-Narrative Systematic Review; David Suzuki Foundation: Vancouver, BC, Canada, 2015.

3. Stone, B. Urban sprawl and air quality in large US cities. J. Environ. Manag. 2008, 86, 688-698. [CrossRef]

4. Carpentieri, M.; Robins, A.G. Influence of urban morphology on air flow over building arrays. J. Wind. Eng. Ind. Aerodyn. 2015, 145, 61-74. [CrossRef]

5. Huang, J.; Li, F.; Zeng, G.; Liu, W.; Huang, X.; Xiao, Z.; Wu, H.; Gu, Y.; Li, X.; He, X.; et al. Integrating hierarchical bioavailability and population distribution into potential eco-risk assessment of heavymetals in road dust: A case study in Xiandao District, Changsha city, China. Sci. Total Environ. 2016, 541, 969-976. [CrossRef]

6. Zeng, J.; Liu, Y.; Feiock, R.; Li, F. The impacts of China's provincial energy policies on major air pollutants: A spatial econometric analysis. Energy Policy 2019, 132, 392-403. [CrossRef]

7. Ding, Y.; Li, G.C.; Lu, X.; Gao, M. Spatial Heterogeneity and Air Pollution Removal by Green Space in Greater Pearl River Delta. Prog. Geogr. 2011, 30, 1415-1421.

8. Jayasooriya, V.; Ng, A.; Muthukumaran, S.; Perera, B. Green infrastructure practices for improvement of urban air quality. Urban For. Urban Green. 2017, 21, 34-47. [CrossRef]

9. Liu, H.; Li, F.; Xu, L.; Han, B. The impact of socio-demographic, environmental, and individual factors on urban park visitation in Beijing, China. J. Clean. Prod. 2017, 163, S181-S188. [CrossRef]

10. Pietrzyk-Kaszy’nska, N.; Czepkiewicz, M.; Kronenberg, J. Eliciting non-monetary values of formal and informal urban green spaces using public participation GIS. Landsc. Urban Plan. 2017, 160, 85-95. [CrossRef]

11. Cohen, P.; Potchter, O.; Schnell, I. A methodological approach to the environmental quantitative assessment of urban parks. Appl. Geogr. 2014, 48, 87-101. [CrossRef]

12. Vieira, J.; Matos, P.; Mexia, T.; Silva, P.; Lopes, N.; Freitas, C.; Correia, O.; Santos-Reis, M.; Branquinho, C.; Pinho, P. Green spaces are not all the same for the provision of air purification and climate regulation services: The case of urban parks. Environ. Res. 2018, 160, 306-313. [CrossRef] [PubMed]

13. McDonald, A.; Bealey, W.; Fowler, D.; Dragosits, U.; Skiba, U.; Smith, R.; Donovan, R.; Brett, H.; Hewitt, C.N.; Nemitz, E. Quantifying the effect of urban tree planting on concentrations and depositions of PM10 in two UK conurbations. Atmos. Environ. 2007, 41, 8455-8467. [CrossRef]

14. Cavanagh, J.A.E.; Zawar-Reza, P.; Wilson, J.G. Spatial attenuation of ambient particulate matters air pollution within an urbanized native forest patch. Urban For. Urban Green. 2009, 8, 21-30. [CrossRef]

15. Yin, S.; Shen, Z.; Zhou, P.; Zou, X.; Che, S.; Wang, W. Quantifying air pollution attenuation within urban parks: An experimental approach in Shanghai, China. Environ. Pollut. 2011, 159, 2155-2163. [CrossRef] [PubMed]

16. Xie, Q.; Zhou, Z.; Chen, F. Quantifying the Beneficial Effect of Different Plant Species in Improving Air Quality. Environ. Eng. Manag. J. 2011, 10, 959-963.

17. Mexia, T.; Vieira, J.; Príncipe, A.; Anjos, A.; Silva, P.; Lopes, N.; Freitas, C.; Santos-Reis, M.; Correia, O.; Branquinho, C.; et al. Ecosystem services: Urban parks under a magnifying glass. Environ. Res. 2018, 160, 469-478. [CrossRef]

18. Davies, Z.G.; Edmondson, J.L.; Heinemeyer, A.; Leake, J.R.; Gaston, K.J. Mapping an urban ecosystem service: Quantifying above-ground carbon storage at a city-wide scale. J. Appl. Ecol. 2011, 48, 1125-1134. [CrossRef]

19. Senanayake, I.; Welivitiya, W.; Nadeeka, P. Urban green spaces analysis for development planning in Colombo, Sri Lanka, utilizing THEOS satellite imagery-A remote sensing and GIS approach. Urban For. Urban Green. 2013, 12, 307-314. [CrossRef]

20. Karagulian, F.; Belis, C.A.; Dora, C.F.C.; Prüss-Ustün, A.M.; Bonjour, S.; Adair-Rohani, H.; Amann, M. Contributions to cities' ambient particulate matter (PM): A systematic review of local source contributions at global level. Atmos. Environ. 2015, 120, 475-483. [CrossRef]

21. Ileperuma, O.A. Environmental pollution in Sri Lanka: A review. J. Natl. Sci. Found. Sri Lanka. 2010, 28, 301-325. [CrossRef] 
22. Chen, F.; Zhou, Z.X.; Xiao, R.B.; Wang, P.C.; Li, H.F.; Guo, E.X. Estimation of ecosystem services of urban green-land in the workshop area of the Wuhan Iron and Steel Company. Acta Ecol. Sin. 2006, 26, 2229-2236.

23. Wang, F.Z. Evaluation on the Ecosystem Services Values of Urban Lake Wetlands: A Case Study of Urban Lake in Wuhan City. Ph.D. Thesis, Huazhong Agriculture University, Wuhan, China, 2010.

24. Kong, D.S.; Zhang, H. Economic value of wetland ecosystem services in the Heihe National Nature Reserve of Zhangye. Acta Ecol. Sin. 2015, 35, 972-983.

25. Price Bureau. 2018. Available online: http://wh.bendibao.com/live/2019529/99151.shtm (accessed on 10 November 2019).

26. Jin, F.; Lu, S.W.; Yu, X.X.; Rao, L.Y.; Niu, J.Z.; Xie, Y.Y.; Zhang, Z.M. Forest ecosystem service and its evaluation in China. Chin. J. Appl. Decol. 2005, 16, 1531-1536.

27. Han, Y.; Zhou, Z. Evaluation on ecosystem services in haze absorption by urban green land and its spatial pattern analysis in Xi'an. Geogr. Res. 2015, 34, 1247-1258.

28. Peng, J.; Wang, Y.L.; Chen, Y.F.; Li, W.F.; Jiang, Y.Y. Economic Value of Urban Ecosystem Services: A Case Study in S hen zhen. Acta Sci. Nat. Univ. Pekin. 2005, 41, 594-604.

29. Duan, Y.B.; Lei, Y.K.; Wu, B.J.; Peng, D.D.; Tian, G.X. Evaluation and dynamic study on the ecological service value for urban green space system in Zhengzhou. Ecol. Sci. 2016, 35, 81-88.

30. Zhang, X.L.; Xu, Z.J.; Zhang, Z.H.; Gu, D.Q.; Wang, L.H. Environment purification service value of urban green space ecosystem in Qingdao City. Acta Ecol. Sin. 2011, 31, 2576-2584.

31. Xu, H.; Liu, X.Y.; An, Z.S.; Hou, Z.H.; Dong, J.B.; Liu, B. Spatial pattern of modern sedimentation rate of Qinghai lake and a preliminary estimate of the sediment flux. Chin. Sci. Bull. 2010, 55, 384-390. [CrossRef]

32. Li, H.; Meier, F.; Lee, X.; Chakraborty, T.; Liu, J.; Schaap, M.; Sodoudi, S. Interaction between urban heat island and urban pollution island during summer in Berlin. Sci. Total Environ. 2018, 636, 818-828. [CrossRef]

33. Zhou, C.S.; Li, S.J.; Wang, S.J. Examining the Impacts of Urban Form on Air Pollution in Developing Countries: A Case Study of China's Megacities. Int. J. Environ. Res. Public Health 2018, 15, 1565. [CrossRef]

34. Tan, P.Y.; Samsudin, R. Effects of spatial scale on assessment of spatial equity of urban park provision. Landsc. Urban Plan. 2017, 158, 139-154. [CrossRef]

35. Rigolon, A.; Browning, M.; Jennings, V. Inequities in the quality of urban park systems: An environmental justice investigation of cities in the United States. Landsc. Urban Plan. 2018, 178, 156-169. [CrossRef] 